\title{
VOLUNTEERING AMONG HIGHER EDUCATION STUDENTS AS PART OF INDIVIDUAL CAREER MANAGEMENT
}

\author{
HAJNALKA FÉNYES - VALÉRIA MARKOS - MÁRTA MOHÁCSI ${ }^{1}$
}

\begin{abstract}
In this study, we examine the motives behind higher education students' volunteering and its determinants based on a survey $(N=2,199)$ conducted in five Central and Eastern European countries. The literature shows that, besides traditional volunteering, which has the objective of helping others, it is also common for the former to engage in career-focused volunteering, which is aimed at networking and the acquisition of work experience and professional knowledge. Our regression results suggest that career-building motivation is more pronounced among women and among those who have close relationships with friends outside higher education institutions, but is considered less important among students in Hungary and those who study sciences, computer science, and engineering. Further regression results show that the likelihood of volunteering being related to the field of study is higher among those with an unfavorable financial situation in the family, students who have a close relationship with faculty, those who study in Romania, and students on teacher training programs.
\end{abstract}

KEYWORDS: motivation for volunteering, higher education students, quantitative analysis, Central and Eastern Europe

1 Hajnalka Fényes is associate professor at the University of Debrecen, Dept. of Sociology and Social Policy, email: fenyes.zsuzsanna@arts.unideb.hu. Valéria Markos is affiliated to CHERD-Hungary, University of Debrecen, email: markosvaleria.90@gmail.com. Márta Mohácsi is senior lecturer at University of Debrecen, Dept. of Sociology and Social Policy, email: mohacsi.marta@arts. unideb.hu. Project no. 123847 was implemented with support provided by the National Research, Development, and Innovation Fund of Hungary, financed under the K_17 funding scheme. 


\section{INTRODUCTION}

Nowadays, volunteering is increasingly popular among higher education students in Central and Eastern Europe. In addition to traditional volunteering, which has the objective of helping others, a novel, career-focused form of volunteering is also on the rise (Bocsi et al. 2017). The latter has the aim of assisting young people to obtain work experience, build relationships, and deepen professional knowledge, and offers a chance for students to test themselves with more than one employer (which the literature calls "revolving-door" volunteering). Based on this, it is possible to consider students' volunteering to be a form of individual career management, as it enhances their subsequent career progress and helps them obtain better positions.

The theoretical part of this study discusses definitions and types of volunteering, as well as the factors which influence students' motivation. We also address the link between volunteering and career management among young people. After formulating our hypotheses, we turn to the empirical section of the study, in which students who did volunteer work during their university years were selected based on data from a survey implemented in five Central and Eastern European countries. A composite index based on four sources of motivation which are related to career-building was then created, and linear regression was used to investigate the relationship between the strength of career-building motivation and background variables (students' gender, age, cultural and financial background, social resources, as well as the country and field of study). We also identify the factors which affect whether voluntary activity is related to the field of study.

\section{DEFINITION, TYPES, AND SOURCES OF MOTIVATION FOR VOLUNTEERING}

The three most important characteristics of volunteering are that it is a non-compulsory activity (that is to say, school community service in secondary schools, introduced in 2012 in Hungary, is not included in the definition), it benefits others (individuals, organizations, or society as a whole), and it is not remunerated. Voicu and Voicu (2003) define volunteering in a narrower sense, considering volunteering to be an activity undertaken within a formal (organizational) framework. Conversely, Wilson (2000) contrasts organizational volunteering with non-organizational volunteering, which is program-centered and does not require formal membership in an organization. 
Several authors point out that volunteering is not a purely altruistic activity as it also creates individual benefits. According to Meijs et al. (2003), the more the costs of a specific activity outweigh its benefits, the more it can be considered voluntary activity. Overall, altruistic or egoistic sources of motivation may also lead to volunteering, while a mix of types of motivation is not uncommon, either. Nowadays, the altruistic nature of volunteering is declining, but the subjective value of volunteering, which includes the need and motivation for pleasure and entertainment, is on the rise. So-called leisure volunteering has also appeared as a phenomenon, although leisure activities can only be considered volunteering if they involve work for the benefit of others (Kaplan 1975; Stebbins 1996). Wollebæk and Selle (2003) found a decline in traditional, value-based volunteering and the increasing importance of cultural and leisure volunteering, volunteering for sports associations, disability support organizations, and neighborhood groups. This novel type of volunteering is characterized by shorter periods of commitment and a high level of fluctuation in organizations.

According to Inglehart (2003), volunteering is not declining; only its nature is changing. Young people are volunteering (especially in charitable and sports organizations) within a new, more flexible, less permanent organizational framework. In addition to leisure volunteering, 'postmodern volunteering' is also common among young people. In the latter, participation itself is important because of the positive feeling of being with others, and because membership provides an identity, as is the case with participation in 'green' and peacesupporting organizations (Inglehart 2003).

Czike and Kuti (2006) distinguish two types of motivation: practical-pragmatic motivation, which is mainly common among young people, and altruisticidealistic motivation, which is characteristic primarily of older religious people. Czike and Bartal (2005) and Perpék (2012) also identify two types of volunteering. On the one hand, there is traditional volunteering, which is based on altruistic motivation ('it is good to help others') with an important element of social interaction and community. On the other hand, the motivation for the modern, novel form of volunteering includes career building, personal and professional development, spending leisure time in a useful way, networking, and obtaining work experience.

Among Romanian university students, Stefanescu and Osvat (2011) distinguished self-interested and professional experience-oriented sources of motivation (networking, meeting people with similar interests, spending leisure time in a useful way, learning and engaging in sports and cultural activities, information acquisition, skills development, increasing employability) and altruistic motivation (considering the benefit to society, acting for others, 
protecting one's own and others' rights and interests). According to their results, young people in Romania are rather characterized by mixed forms of motivation, whereby career-building goals and the intention to help are both important.

\section{THE LINK BETWEEN CAREER MANAGEMENT AND VOLUNTEERING AMONG YOUNG PEOPLE}

According to Soós (2007), a career usually involves professional advancement as well as social and financial success. A career includes a person's time spent at work, an individual's professional path and development, skills improvement, and self-realization. Career management is part of human resource management, which can occur at the individual or organizational level. At the organizational level, the company creates development and advancement opportunities for its employees (Koncz 2002). However, career management can also be interpreted at the individual level. Nowadays, when planning their careers, employees primarily focus on satisfying their own needs and engaging their interests, but it is possible to coordinate individual and organizational goals (Soós 2007).

"Career awareness" can also be associated with young people in the sense that they may become aware of career opportunities and related requirements when choosing a profession. At the end of secondary school, career-conscious students decide on a higher education program based on the ease of finding a job after graduating, the prestige of the profession, and the income thereby attainable (Tuckman 1974; Molnárné 2014).

According to Mohácsi and Fényes (2020), career-conscious university students, when deciding whether to study further, primarily take into account the components of the human capital model (the wage advantage of a degree, having a prestigious profession, and shorter job search), and are also committed to completing their studies and are willing to make efforts to that end. According to their empirical findings, career-conscious attitudes are stronger among women, those from rural areas and from objectively well-off families, and students who study business or economics.

As regards the sources of motivation for volunteering, it is clear that a new type of volunteering has appeared among young people that is aimed at career building. In addition, it is important to emphasize that young people find it a substantial barrier to job searching that many employers require them to have completed multiple years of internship (Soós 2007). According to Handy et al. (2010), students sometimes do volunteer work with the intention of including it in their curricula vitae. However, this source of motivation is not as strong in 
Central and Eastern Europe as it is, for example, in the US and Canada. The majority of employers there take into account in job interviews whether someone has been a volunteer, while in our region this is still a rarity. In addition, Handy et al. (2010) also point out that higher education students' career-building sources of motivation are not necessarily egoistic but rather signal to the employer that a candidate is career conscious and better suited to the job than someone who has not volunteered. In this case, however, it is important that the volunteer work should align with students' career plans, and potentially even with their field of study, inasmuch as they wish to pursue a profession in that field.

A concept which is related to the above is "experimental socialization," which requires more activity from young people and is characterized by experimentation, change, and a novel start. In accordance with the concept, young people frequently engage in so-called "revolving-door volunteering," which lasts for a relatively short period of time but has the potential of offering variety and allows young people to try themselves out at several organizations, which may help them find a suitable job later (Hustinx 2001). In the case of revolving-door volunteering, it is also possible that after trying some jobs students' career plans will change and they will make more conscious choices when looking for a position after graduating, which also benefits employers as it decreases the risk of mismatch.

Another feature of young people's volunteering is capital conversion (Bourdieu 1986). Although no remuneration is offered for volunteering, young people thereby make useful relationships and obtain knowledge (cultural capital), which they can later turn into economic benefits. It can also be assumed that disadvantaged students who might not receive these forms of capital at home may compensate for their disadvantages through volunteer work. Additionally, volunteering has the advantage of socializing young people into the world of labor. It can teach them the basic rules of jobs, as well as about norms, teamwork, conflict management, etc., which they might not have mastered during higher education.

In the United Kingdom, a number of studies have examined the effectiveness of higher education students' volunteering in terms of building their careers. According to quantitative analysis by Hoskins, Leonard and Wilde (2020), students from an unfavorable background have limited access to volunteer work in the private sector that may easily be converted be into favorable jobs, so the positive impact of volunteer work on later employment cannot be clearly demonstrated. In many cases, students from unfavorable social backgrounds experience that volunteering does not pay off as an investment. According to the authors' qualitative interview analysis, three types of volunteer students can be differentiated: career-specific volunteers; volunteers who wish to improve 
their career-related skills; and finally, students for whom volunteering is a kind of punishment due to its compulsory nature (since it is part of the curriculum, and academic credit is awarded for it). The interviews reveal that volunteering does not have a positive effect on employment if it is "compulsory" or is not related to the field of study. Barton, Bates and O'Donovan (2019) showed, using data from interviews carried out in the United Kingdom, that many students reported positive experiences in connection with volunteering (in terms of help with career development, for including on a résumé, for helping find a job in which they can succeed, and contributing to learning through experience and skills development), but the volunteering experience was sometimes negatively assessed in job interviews when it was not related to career goals. Anderson and Green (2012) are also skeptical of the claim that volunteering helps students in all situations, especially if it is part of a curriculum (i.e., is mandatory).

\section{FACTORS INFLUENCING THE MOTIVATION FOR VOLUNTEERING}

The international literature mostly addresses traditional volunteering, which is based on altruistic values and devotes little attention to modern volunteering, which is more popular among young people. Furthermore, higher education students' motivation for volunteering and its determinants are examined very rarely. Usually, it is only psychologists who investigate the types of motivation, but they often fail to examine social background and similar factors as explanatory variables.

The results of international surveys of young people aged 18-30 show that diverging demographic and social backgrounds are associated with differences in volunteering (Flash Eurobarometer 2019) and forms of motivation (MeierStutzer 2008). The evidence suggests that relatively more women are involved in voluntary activities than men (Oesterle et al. 2004), and their primary motivation for volunteering is to help others. Female higher education students are characterized by traditional volunteering and membership in voluntary organizations, while males are more likely to take part in modern volunteering in sports associations, cultural and non-governmental organizations, nature conservation groups, and political organizations (Fényes-Pusztai 2012a). It is also apparent that urban residents are more willing to participate in voluntary activities than rural residents (Juknevičiusa-Savicka 2003; Flash Eurobarometer 2019), but with respect to motivation, altruistic motives may be more common among those who live in villages due to the higher degree of group solidarity 
(Wirth 1973). According to Fényes (2015), having an urban residence in childhood strengthens mixed volunteering motivation among higher education students.

Several studies have found that religiosity has a positive effect on volunteering (Becker-Dhingra 2001; Wilson-Janoski 1995; Wilson-Musick 1997). In particular, Paxton et al. (2014) found that individual religious practice (e.g. regular prayer) is more decisive, while others argue that collective religious practice (e.g. church attendance) increases the likelihood of volunteering more (Wilson-Musick 1997; Becker-Dhingra 2001; Voicu-Voicu 2003; Ruiter-De Graaf 2006; Van Tienen et al. 2011). Storm (2015) explains this by the fact that there are many opportunities for voluntary activity in religious communities, and that church teachings compel religious people to regard the act of helping as a moral obligation. Psychologists have shown that altruism and religiosity are positively correlated with volunteering among higher education students, but the attitude of wishing to help others (altruism) is a more important predictor of volunteering than religiosity itself (Eubanks 2008). Findings by Fényes and Pusztai (2012b) suggest that religious students are not overrepresented in traditional volunteering. A cluster analysis based on six different sources of motivation for volunteering revealed no significant relationship between different dimensions of religiosity and cluster membership. Fényes (2015), in a factor analysis that incorporated 21 sources of motivation for volunteering, also found that religious students were not more likely than others to participate in traditional volunteering. The reason may be the lack of sources of motivation that are unambiguously traditional or modern, as helping others seems to be also important for modern volunteers.

Of the countries examined in this study, Fényes and Pusztai (2012b) showed that Romania had more modern and career-building volunteers than volunteers who only had the objective of helping others. At the same time, there were more purely help-oriented volunteers in Ukraine and Hungary, where modern volunteering with mixed sources of motivation was also present, albeit with no importance attached to the inclusion of volunteer experience in curricula vitae. Fényes (2015) showed using data from 2014 that mixed sources of motivation were stronger in the Romanian and Ukrainian subsamples than in Hungary. According to another analysis by Bocsi et al. (2017), mixed sources of motivation were present in similar proportions in the four examined countries (Hungary, Romania, Ukraine, and Serbia). In the Ukrainian subsample, however, volunteers were not at all influenced by other volunteers among their friends and family, or by the potential inclusion of volunteer experience on their résumés. This was explained by the relatively low level of development of volunteering culture in Ukraine compared to other countries. 


\section{HYPOTHESES}

H1: Based on the literature (Hustinx 2001; Inglehart 2003; Meijs et al. 2003; Handy et al. 2010; Stefanescu-Osvat 2011; Fényes-Pusztai 2012a; Perpék 2012; Fényes 2015; Bocsi et al. 2017), we assume that higher education students are also driven to volunteering, besides having a desire to help, by the motivation to obtain professional experience, to acquire knowledge and develop professionally, to make new friends and acquaintances, and to include the experience on their résumé.

In another research question, we investigate the factors which affect the strength of career-building sources of motivation, as well as whether volunteering is related to the field of study. As regards demographic variables, Mohácsi and Fényes (2020) argue that women in higher education have greater career awareness than men, and Fényes (2015) has found that help-focused and simultaneously career-building sources of motivation are more prevalent among women than men.

H2A: We assume that career-building motivation is more pronounced among women, and that volunteering is more often related to the field of study among them.

H2B: Based on Hustinx (2001) and Fényes (2015), we assume that older students are disproportionately characterized by having a career-building motivation for volunteering, and that volunteering is more often related to the field of study among them.

As regards higher education students' social background, we investigate the effect of their financial, cultural and social resources, as well as the impact of their place of residence at the age of 14. Fényes (2015) argues that an unfavorable subjective financial situation increases career-building sources of motivation, whereas Mohácsi and Fényes (2020) find that broadly defined career awareness is greater among children from families with a favorable objective financial situation.

H3A: We hypothesize that the effect of financial background could be ambiguous, and that parents' educational attainment does not affect the strength of career-building sources of motivation.

As Perpék (2012) highlights, social resources have a stronger impact on volunteering than the usual socio-demographic variables.

H3B: We presume that an extensive network of relationships strengthens career-building motivation, and that the likelihood that volunteering is related to the field of study is especially increased by a close relationship with faculty.

H3C: We assume that urban residence increases the likelihood of career-building motivation (Wirth 1973; Fényes 2015), although Mohácsi and 
Fényes (2020) find greater career awareness in the general sense among students from a rural environment.

We present findings for two indicators with respect to the characteristics of training - namely, the country, and the field of training.

H4A: We assume that in those countries we examined where the culture of volunteering is more advanced and the non-profit sector is more developed, career-building motivation among students is more pronounced, which can be explained by the larger diversity of volunteering opportunities (Fényes-Pusztai 2012b; Fényes 2015; Bocsi et al. 2017).

H4B: Finally, we assume that career-building goals are more likely to prevail among students engaged in helping professions, wherein volunteer work is to a large extent related to the field of study, as opposed to programs in business, economics, sciences, computer science, and engineering.

\section{DATA, METHODS, VARIABLES}

The database consists of a large-sample student survey ${ }^{2}(\mathrm{~N}=2,199)$ conducted in the academic year 2018/19. The survey was carried out at higher education institutions in Eastern Hungary ${ }^{3}$ and in four other countries ${ }^{4}$ (Slovakia, Romania, Ukraine, and Serbia). The Hungarian subsample $(\mathrm{N}=1,034)$ was collected using quota sampling and is representative with respect to faculty, field of study, and form of funding. At institutions outside Hungary, groups of students in randomly selected university or college courses were surveyed exhaustively $(\mathrm{N}=1,165)$. The sample consists of full-time bachelor's students in their second year, and second-year or third-year students from undivided programs which offer a master's degree.

We selected students from the sample who had done volunteer work with some frequency during their studies $(46.8 \%)$. We then performed cluster analysis and factor analysis using the sources of motivation for volunteering (see

2 The title of the research project was "The Role of Social and Organizational Factors in Student Attrition."

3 University of Debrecen, University of Nyíregyháza, Debrecen Reformed Theological University, Saint Athanasius Greek Catholic Theological College.

4 Babeş-Bolyai University (BBTE), Emanuel University of Oradea, Ferenc Rákóczi II Transcarpathian Hungarian College of Higher Education, Constantine the Philosopher University in Nitra, Mukachevo State University, University of Oradea, Partium Christian University (PKE), Sapientia Hungarian University of Transylvania, J. Selye University, University of Novi Sad, Uzhhorod National University. 
Table 1 for the eight possible sources of motivation used in the questionnaire, with their importance judged by respondents on a scale of 1-4), but the results were difficult to interpret. As a result, we decided to create an index based on four sources of motivation which represent career-building features (obtaining professional experience; obtaining knowledge and developing professionally; making new friends and acquaintances; including volunteering on a résumé).

Subsequently, we conducted linear regression analysis to explore the relationship between the strength of career-building sources of motivation (index) and background variables. We also carried out logistic regression to examine the determinants of whether volunteering was related to the field of study.

In both regression models, explanatory variables include gender $(30.1 \%$ male and $69.9 \%$ female) and age (with a mean of 21.6 and a standard deviation of 1.62). We examined students' social background based on Bourdieu's (1986) capital theory, as we differentiated between students' cultural, financial, and social resources. We proxy cultural background using the father's and mother's years of education (with a mean of 12.7 and a standard deviation of 2.54, and a mean of 12.9 and a standard deviation of 2.6, respectively). Concerning financial status, we have four indicators. The family's financial situation was measured by the possession of durable consumer goods ${ }^{5}$ (objective financial situation index $0-9$, with a mean of 6.9 and a standard deviation of 1.63) and by a relative financial situation indicator, which compares the family's financial situation to the student's peers (on a $1-5$ scale, where 3 is the average situation, with a mean of 3.3 and a standard deviation of 0.77 ). To capture the students' individual financial situation objectively, we created a composite index indicating the possession of durable goods ${ }^{6}(0-6$, with a mean of 1.8 and a standard deviation of 1.5) and a subjective indicator of individual financial situation ${ }^{7}$ to explore whether the student can afford a significant purchase or is unable to cover even their basic expenses (1-4, with a mean of 3.2 and a standard deviation of 0.62 ). Finally, the variable for the place of residence at the age of 14 (1: urban, 0: rural)

\footnotetext{
5 Components of the index: Does the family possess any of the following items? An apartment or house, a five-year-old car or younger, a flat-screen television, a personal computer or laptop with broadband internet access at home, a tablet or e-book reader, mobile internet (on the phone or computer), a dishwasher, an air-conditioner, and a smartphone.

6 Components of the index: Does the student possess any of the following items: An apartment or house, a car, an above-average smartphone (e.g. iPhone), an above-average computer or laptop, a tablet or e-book reader, and savings for a house purchase?

7 1: Often I do not have enough money for basic everyday necessities. 2: Sometimes I do not have enough money for everyday expenditures. 3: I have everything I need but cannot afford larger expenditures. 4: I have everything I need and can also afford larger expenditures.
} 
is also included (with $62.2 \%$ of respondents as urban residents). Students' social resources are represented by four indices, measuring the frequency of social activities with parents ${ }^{8}$ (6-30, with a mean of 19.6 and a standard deviation of $3.44)$, faculty ${ }^{9}(0-18$, with a mean of 4.2 and a standard deviation of 4.19$)$, fellow students from the same program or institution ${ }^{10}(0-11$, with a mean of 8.3 and a standard deviation of 2.84), and friends outside the institution ${ }^{11}(0-11$, with a mean of 7.7 and a standard deviation of 3.16).

We also investigate the effect exerted by the characteristics of education, as represented by two variables. The country of education has the following distribution in the sample: $47.5 \%$ Hungary, 32\% Romania, 9.3\% Ukraine, $6.4 \%$ Slovakia, $4.8 \%$ Serbia (we created dummy variables with Serbia as the reference group). We classified the fields of study into five categories: arts and social sciences, $21.5 \%$; economics and business, $12.7 \%$; computer science, engineering and sciences, $15.9 \%$; previously unclassified teacher education, $25.7 \%$; other $24.2 \%$; and we created four dummy variables, where the reference group was the "other" category.

\section{RESULTS}

Among those who had done volunteer work with some frequency $(46.8 \%$ of the sample, $\mathrm{N}=939$ ), Table 1 presents the sources of motivation of volunteering in order of importance.

8 During the years spent in higher education, have your parents done any of the following activities with you? Having a conversation; asking about your studies and exams; providing financial support; planning activities together; planning sports activities together (the frequency of the activities is specified on a 1-5 scale, with Cronbach's Alpha at 0.793 ).

9 Do you have a professor or lecturer with whom you do any of the following activities? Talking about the curriculum outside lectures; talking about topics not specified in the curriculum; talking about literature or art; talking about questions of politics; talking about private matters; talking about plans for the future; maintaining regular e-mail conversations; paying special attention to your career; talking about sport and healthy lifestyles (1: there is one such professor; 2 : there are more; 0: there is none; with Cronbach's Alpha at 0.879).

10 Do you have a fellow student in the program or at the institution with whom you do the following activities? Talking about academic problems; talking about private matters; spending leisure time together frequently; discussing future plans; visiting in case of illness; borrowing textbooks or study material; talking about scientific questions; talking about culture or questions of politics; talking about art; studying together; doing sports together (1: yes, 0: no; with Cronbach's Alpha at 0.842 ).

11 Do you have a friend outside the institution with whom you do the following activities? See the list for fellow students (1: yes, 0: no; with Cronbach's Alpha at 0.873). 
Table 1. Sources of motivation of volunteering in order of importance (1-4 scale, mean, standard deviation, share of 'important' and 'very important' answers)

\begin{tabular}{cccc}
\hline & Mean & $\begin{array}{c}\text { Standard } \\
\text { deviation }\end{array}$ & $\begin{array}{c}\text { 'Important' and 'very } \\
\text { important' }\end{array}$ \\
\hline To help others & 3.30 & 0.71 & $90.1 \%$ \\
\hline To obtain professional experience & 3.08 & 0.84 & $79.9 \%$ \\
\hline To obtain knowledge and develop professionally & 3.07 & 0.86 & $81.5 \%$ \\
\hline To feel better & 3.05 & 0.76 & $81.9 \%$ \\
\hline To make new friends and acquaintances & 2.99 & 0.83 & $76.1 \%$ \\
\hline To include it on my résumé & 2.35 & 0.98 & $44.7 \%$ \\
\hline Because of my religious beliefs & 2.28 & 1.05 & $43.6 \%$ \\
\hline $\begin{array}{c}\text { Because friends or family members also do } \\
\text { volunteer work }\end{array}$ & 2.25 & 0.96 & $39.7 \%$ \\
\hline
\end{tabular}

Source: Authors' calculations based on PERSIST 2019

Based on our results, the most important source of motivation among students was helping others: over $90 \%$ of volunteers marked this as an important or very important aspect. Career-building sources of motivation (to obtain professional experience, to gain knowledge and develop professionally, to make friends and acquaintances) were somewhat less important (76-82\%), while the inclusion of volunteering on the respondents' résumé as a source of motivation was important only for $45 \%$ of students in the examined region. Interestingly, even among those with pronounced career-building goals, onethird of the volunteer work was not related to the field of study, which might imply that some people compensate for a misguided choice of career or study program with volunteering and prefer to gain experience for a subsequent profession through voluntary activity. Another conceivable explanation is that respondents believe that, even if their volunteer work is not related to the field of study, they could still benefit in their subsequent career from the acquisition of professional experience in another field through networking and professional development.

In the following, we present linear regression results with respect to the effect of background variables on the index for career-building sources of motivation ${ }^{12}$ (Table 2).

12 The components of the index were the following: to obtain professional experience; to obtain knowledge and develop professionally; to make new friends and acquaintances; to include volunteering on my résumé. 
Table 2. The effect of various factors on the index for career-building sources of motivation - linear regression betas and their significance $(N=939)$

\begin{tabular}{|c|c|c|}
\hline & Beta & Sig. \\
\hline Gender (1: male) & -0.082 & 0.036 \\
\hline Age & 0.015 & 0.700 \\
\hline Mother: years of education & 0.051 & 0.247 \\
\hline Father: years of education & 0.012 & 0.783 \\
\hline $\begin{array}{l}\text { Family's objective financial situation based on the possession of } \\
\text { durable consumer goods (index, } 0-9 \text { ) }\end{array}$ & 0.009 & 0.831 \\
\hline Family's relative financial situation compared to the student's peers $(1-5)$ & 0.066 & 0.128 \\
\hline $\begin{array}{l}\text { Student's objective financial situation based on the possession of } \\
\text { durable consumer goods (index, } 0-6 \text { ) }\end{array}$ & -0.042 & 0.321 \\
\hline Student's subjective financial situation (1-4) & 0.020 & 0.634 \\
\hline Place of residence at the age of 14 (1: urban) & -0.009 & 0.807 \\
\hline Index for relationship with parents & 0.070 & 0.068 \\
\hline Index for relationship with faculty & 0.025 & 0.533 \\
\hline Index for relationship with university peers & 0.075 & 0.059 \\
\hline Index for relationship with external friends & 0.118 & 0.003 \\
\hline Hungary & -0.120 & 0.049 \\
\hline Romania & 0.009 & 0.878 \\
\hline Ukraine & -0.083 & 0.060 \\
\hline Slovakia & -0.031 & 0.472 \\
\hline Arts and social sciences & 0.025 & 0.588 \\
\hline Business and economics & 0.016 & 0.713 \\
\hline Sciences, computer science, engineering & -0.137 & 0.001 \\
\hline Teacher education & -0.019 & 0.712 \\
\hline Adjusted R-squared & 0.087 & \\
\hline
\end{tabular}

Source: Authors' calculations based on PERSIST 2019

Career-building sources of motivation were significantly $(\mathrm{p}<0.05)$ increased by students' gender (female) and close relationships with external friends (from outside the institution). The opposite (negative) effect can be observed for Hungary and for the fields of sciences, computer science, and engineering. We also undertook logistic regression analysis to examine the extent to which the background variables we included affected whether volunteering was related to the field of study, which is also an important variable in terms of the career management of higher education students (Table 3). 
Table 3. Determinants of the nature of volunteering (1: related to the field of study, 0: not related) - logistic regression $\operatorname{Exp}(B)$ and the significance of Wald statistics $(N=939)$

\begin{tabular}{|c|c|c|}
\hline & $\operatorname{Exp}(B)$ & $\begin{array}{c}\text { Sig. } \\
\text { Wald statistics }\end{array}$ \\
\hline Gender (1: male) & 0.741 & 0.141 \\
\hline Age & 1.085 & 0.199 \\
\hline Mother: years of education & 1.050 & 0.230 \\
\hline Father: years of education & 0.978 & 0.590 \\
\hline $\begin{array}{l}\text { Family's objective financial situation based on the possession of } \\
\text { durable consumer goods (index, } 0-9 \text { ) }\end{array}$ & 0.870 & 0.033 \\
\hline $\begin{array}{l}\text { Family's relative financial situation } \\
\text { compared to the student's peers }(1-5)\end{array}$ & 1.280 & 0.061 \\
\hline $\begin{array}{l}\text { Student's objective financial situation based on the possession of } \\
\text { durable consumer goods (index, } 0-6 \text { ) }\end{array}$ & 1.069 & 0.338 \\
\hline Student's subjective financial situation (1-4) & 1.025 & 0.882 \\
\hline Place of residence at the age of 14 (1: urban) & 1.289 & 0.169 \\
\hline Index for relationship with parents & 0.995 & 0.850 \\
\hline Index for relationship with faculty & 1.057 & 0.011 \\
\hline Index for relationship with university peers & 1.062 & 0.129 \\
\hline Index for relationship with external friends & 1.030 & 0.370 \\
\hline Hungary & 0.904 & 0.723 \\
\hline Romania & 1.948 & 0.017 \\
\hline Ukraine & 0.396 & 0.046 \\
\hline Slovakia & 0.377 & 0.033 \\
\hline Arts and social sciences & 1.411 & 0.176 \\
\hline Business and economics & 0.461 & 0.012 \\
\hline Sciences, computer science, engineering & 0.398 & 0.001 \\
\hline Teacher education & 2.216 & 0.004 \\
\hline Nagelkerke R-squared & & 0.218 \\
\hline
\end{tabular}

Source: Authors' calculations based on PERSIST 2019

According to the results, the likelihood that volunteering is related to the field of study is significantly higher among those with an unfavorable objective (family) financial situation, students who have a close relationship with faculty, those who study in Romania as opposed to Ukraine and Slovakia, and students who are training as teachers. Volunteering is less likely to be related to the field of study among students of economics, business, sciences, computer science, or engineering. 


\section{CONCLUSION}

Based on the literature (Hustinx 2001; Inglehart 2003; Meijs et al. 2003; Handy et al. 2010; Perpék 2012), we assumed that higher education students are also driven to volunteer, besides the desire to help, by the wish to advance their careers. Our data show, however, that the most important motive is still helping others, and career-building sources of motivation are somewhat less important, so our first hypothesis only partly supported. The explanation may be that motives for volunteering in this region are mixed: in most cases, careerbuilding motives are combined with altruistic ones (see Stefanescu-Osvat 2011; Fényes-Pusztai 2012a; Fényes 2015; Bocsi et al. 2017).

Interestingly, even among those who have strong career-building goals, onethird of volunteer work was not related to the field of study, which may be because students use volunteering to make up for a misguided choice of study program. It is also possible, however, that students find work experience, social capital, and knowledge obtained from other fields to be important for building their current careers.

We created a composite index based on four career-building motives (to obtain professional experience, to gain knowledge and develop professionally, to make new friends and acquaintances, and to include volunteering on a résumé). We carried out linear regression analysis to investigate which variables increase the strength of these motives. We also revealed through logistic regression analysis the factors which affect whether volunteering is related to the field of study.

Regarding demographic variables, females have stronger career-building motives than males, in line with our second hypothesis and the literature (Mohácsi-Fényes 2020; Fényes 2015), but we found no effect with respect to the age of students, in contrast to findings by Hustinx (2001) and Fényes (2015). The reason may be that the sample was quite homogeneous in terms of age.

As regards higher education students' social background, our data show only one significant effect - namely, that students with an unfavorable objective family financial situation are more likely to do volunteer work related to the field of study, which is a positive result and is partly in line with our third hypothesis and previous findings by Fényes (2015). As for students' social resources, we found that a close relationship with faculty increases the likelihood that volunteering is related to the field of study, in accordance with our third hypothesis. We also found that a close relationship with friends outside the institution increases career-building sources of motivation, which is also in line with our hypothesis.

As regards the characteristics of training, volunteering is more frequently related to the field of study in Romania as opposed to Ukraine, while careerbuilding motives seem to be more pronounced among students outside Hungary, 
so our fourth hypothesis was not supported and the results are not in line with the literature either (Fényes-Pusztai 2012b; Fényes 2015; Bocsi et al. 2017). The reason may be that students in Romania receive academic credit for volunteer work which is related to their studies. Furthermore, career-building motives may be stronger outside Hungary because most of the surveyed students in the other four countries were students of teacher training, which is a helping profession, and career goals in connection with volunteering may be more pronounced among them.

As expected, students in helping professions, which in this case covered mostly students of teacher training, were much more likely to associate volunteering with their field of study compared to those in economics, business, or STEM (engineering, computer science and natural sciences) programs, a finding which is in line with our fourth hypothesis. Career-building motives are also stronger outside the fields of sciences, computer science, and engineering.

\section{Policy recommendations}

As explained in the theoretical part of our study, volunteering in contemporary higher education assists students to plan their careers (e.g. by helping them try themselves out in several fields during "revolving-door volunteering"), as well as in building it (through the acquisition of useful knowledge, relationships, and professional experience). Furthermore, it is conceivable that students who enjoy volunteer work at organizations may decide to work at the latter permanently. Career guidance has been a major goal of school community service which was introduced into secondary schools across Hungary in 2012. In addition, volunteering may also be useful for establishing professional relationships and obtaining professional knowledge in practice, if such volunteering is related to the field of higher education studies, thus complements traditional higher education. Due to the above advantages, we recommend that universities in the examined Central and Eastern European region should encourage volunteering among students, even in an organized way, and potentially reward it with credits (e.g. in Romania, volunteering has been recognized as a form of internship since 2014 - which is not common in the other countries under analysis, however). It is also recommended to operate career offices at faculties and departments where students may be offered voluntary and paid work opportunities which are related to the profession, and are manageable alongside academic requirements. In addition, higher education institutions can employ dedicated professionals to coordinate volunteering and discuss related experiences. We must mention, however, that certain studies in the literature (which are presented in the 
theoretical section and based on UK data) show that the career-building motivation for volunteering is not prevalent among students with an unfavorable social background if volunteering is compulsory, and if it is not related to the field of study, which should be taken into account by education policy actors. Our findings show, however, that volunteering is more likely to be related to the field of study in our examined region for students with an unfavorable objective financial situation in the family, which is a positive result.

According to our additional findings, career-building goals associated with volunteer work are more pronounced among females, students with close relationships with friends outside their own educational institution, and students of fields other than sciences, computer science, and engineering. In addition, volunteering is more often related to the field of study among students of teacher training compared to students of sciences, economics, and business, indicating that the former might manage to take better advantage of the career-building potential of volunteering. Consequently, higher education policy should also pay attention to students who do not have a career-building attitude towards volunteering by drawing their attention to the positive impact volunteering could have on their development. An additional finding is that having a close relationship with faculty increases the likelihood that volunteering is related to the field of study. This implies that professors and lecturers can also contribute to the realization of students' subsequent career plans by offering them suitable volunteer work.

\section{REFERENCES}

Anderson, P. - P. Green (2012) Beyond CV building: The communal benefits of student volunteering. Voluntary Sector Review, Vol. 3, No. 2., pp. 247-256, DOI: https://doi.org/10.1332/204080512X649388

Barton, E. - E. Bates - R. O'Donovan (2019) 'That extra sparkle': Students' experiences of volunteering and the impact on satisfaction and employability in higher education. Journal of Further and Higher Education, Vol. 43, No. 4., pp. 453-466, DOI: https://doi.org/10.1080/0309877X.2017.1365827

Becker, E. P. - H. P. Dhingra (2001) Religious involvement and volunteering: Implications for civil society. Sociology of Religion, Vol. 62, No. 3., pp. 315-335, DOI: $10.2307 / 3712353$

Bocsi, V. - H. Fényes - V. Markos (2017) Motives of volunteering and values of work among higher education students. Citizenship Social and Economics Education, Vol. 16, No. 2., pp. 117-131, DOI: https://doi. org/10.1177/2047173417717061 
Bourdieu, P. (1986) The Forms Of Capital. In: Richardson, J. G. (ed.): Handbook of Theory and Research for the Sociology of Education. New York, NY, Greenwood Press, pp. 241-258, DOI: 10.2307/1175546

Czike, K.-A. Bartal(2005) Önkéntesekés non-profitszervezetek [Volunteers and Non-Profit Organizations]. Piliscsaba (Hungary), Országos Foglalkoztatási Közalapítvány and Pázmány Péter Katolikus Egyetem

Czike, K. - É. Kuti (2006) Önkéntesség, jótékonyság és társadalmi integráció [Volunteering, Charity and Social Integration]. Budapest, Nonprofit Kutatócsoport Egyesület, Önkéntes Központ Alapítvány

Eubanks, A. C. (2008) To What Extent It Is Altruism? An Examination of How Dimensions of Religiosity Predict Volunteer Motivation amongst College Students. PhD dissertation, Carbondale (IL), Southern Illinois University

Fényes, H. (2015) Effect of religiosity on volunteering and on the types of volunteering among higher education students in a cross-border CentralEastern European Region. Acta Universitatis Sapientiae. Social Analyses, Vol. 5, No. 2., pp. 181-203.

Fényes, H. - G. Pusztai (2012a) Volunteering among higher education students. Focusing on the micro-level factors. Journal of Social Research and Policy, Vol. 3, No. 1., pp. 73-96.

Fényes, H. - G. Pusztai (2012b) Religiosity and Volunteering among Higher Education Students in the Partium Region. In: Györgyi, Z. - Z. Nagy (eds.): Students in a Cross-Border Region. Higher Education for Regional Social Cohesion. Nagyvárad (Oradea, Romania), University of Oradea Press, pp. 147-167.

Flash Eurobarometer (2019) http://forumfrancaisjeunesse.fr/wp-content/ uploads/2019/08/stronger_united_Europe_views-of-young-people.pdf [Last access: 0912 2020]

Handy, F. - R. A. Cnaan - L. Hustinx - Ch. Kang - J. L. Brudney - D. HaskiLeventhal - K. Holmes - L. C. Meijs - A. B. Pessi-B. Ranade - N. Yamauchi - S. Zrinscak (2010) A cross-cultural examination of student volunteering: Is it all about résumé building? Nonprofit and Voluntary Sector Quarterly, Vol. 39. No. 3., pp. 498-523, DOI: https://doi.org/10.1177/0899764009344353

Hoskins, B. - P. Leonard - R. Wilde (2020) How effective is youth volunteering as an employment strategy? A mixed methods study of England. Sociology, Vol. 54, No. 4., pp. 763-781, DOI: https://doi.org/10.1177/0038038520914840

Hustinx, L. (2001) Individualization and new styles of youth volunteering: An empirical exploration. Voluntary Action, Vol. 3, No. 2., pp. 57-76.

Inglehart, R. (2003) Modernization and Volunteering. In: Dekker, P. - L. Halman (eds.): The Values of Volunteering. Cross-Cultural Perspectives. New York, Boston, Dordrecht, London, Moscow, Kluver Academic/Plenum Publishers, pp. 55-70, DOI: 10.1007/978-1-4615-0145-9 
Juknevičiusa, S. - A. Savicka (2003) From Restitution to Innovation: Volunteering in Postcommunist Countries. In: Dekker, P. - L. Halman (eds.): The Values of Volunteering. Cross-Cultural Perspectives. New York, Boston, Dordrecht, London, Moscow, Kluver Academic/Plenum Publishers, pp. 127-141. DOI: 10.1007/978-1-4615-0145-9

Kaplan, M. (1975) Leisure Theory and Policy. New York, Wiley. DOI: https:// doi.org/10.1080/00222216.1977.11970303

Koncz, K. (2002) Életpálya és munkahelyi karriermenedzsment [Career and workplace career management]. Vezetéstudomány, Vol. 33, No. 4., pp. 2-14.

Meier, S. - A. Stutzer (2008) Is volunteering rewarding in itself? Economica, Vol. 75, No. 297., pp. 39-59, DOI: https://doi.org/10.1111/j.1468-0335.2007.00597.x Meijs, L. -F. Handy-R. Cnaan-J. Brudney-U. Ascoli-S. Ranade-L. Hustinx S. Weber - I. Weiss (2003) All in the Eyes of the Beholder? Perceptions of Volunteering Across Eight Countries. In: Dekker, P. - L. Halman (eds.): The Values of Volunteering. Cross-Cultural Perspectives. New York, Boston, Dordrecht, London, Moscow, Kluver Academic/Plenum Publishers, pp. 19-34, DOI: $10.1007 / 978-1-4615-0145-9$

Mohácsi, M. - H. Fényes (2020) A karriertudatosság és az arra ható tényezők a felsőoktatási hallgatók körében. Egy közép-kelet európai régióban végzett kutatás eredményei [Career consciousness and its determinants among higher education students. Results of a survey in a region of Central and Eastern Europe]. Tér-Gazdaság-Ember, Vol. 8, No. 3., pp. 47-61.

Molnárné Konyha, Cs. (2014) A továbbtanulási tudatosság fogalmi meghatározása és egy lehetséges mérési módszere [The Definition and a Possible Measurement Method of Consciousness in the Choice of Study Program]. In: Piskóti, I. (ed.): Marketingkaleidoszkóp 2014. Innovációvezérelt marketing [Marketing Kaleidoscope 2014. InnovationDriven Marketing]. Miskolc (Hungary), Miskolci Egyetem, Marketing Intézet, pp. 203-209,

Oesterle, S. - M. Kirkpatrick Johnson - J. T. Mortimer (2004) Volunteerism during the transition to adulthood: A life course perspective. Social Forces, Vol. 82, No. 3., pp. 1123-1149, DOI: https://doi.org/10.1353/ sof.2004.0049

Paxton, P. - N. E. Reith - J. L. Glanville (2014) Volunteering and the dimensions of religiosity: A cross-national analysis. Review of Religious Research, Vol. 56, No. 4., pp. 597-625, DOI: 10.1007/s13644-014-0169-y

Perpék, É. (2012) Formal and informal volunteering in Hungary, similarities and differences. Corvinus Journal of Sociology and Social Policy, Vol. 3, No. 1., pp. 59-80, DOI: 10.14267/issn.2062-087X 
Ruiter, S. - N. D. De Graaf(2006) National context, religiosity, and volunteering: Results from 53 countries. American Sociological Review, Vol. 71, No. 3., pp. 191-210, DOI: https://doi.org/10.1177/000312240607100202

Soós, J. K. (2007) Karrier összehangolása egyéni és szervezeti szinten. [Career harmonization at the individual and organizational level]. Munkaügyi Szemle, Vol. 51, No. 4., pp. 20-24.

Stebbins, R. A. (1996) Volunteering: A serious leisure perspective. Nonprofit and Voluntary Sector Quarterly, Vol. 25, No. 2., pp. 211-224, DOI: https://doi. org $/ 10.1177 / 0899764096252005$

Stefanescu, F. - C. Osvat (2011) Volunteer landmarks among college students. The Yearbook of the „Gh. Zane” Institute of Economic Researches, Vol. 20, No. 2., pp. 139-149.

Storm, I. (2015) Religion, inclusive individualism, and volunteering in Europe. Journal of Contemporary Religion, Vol. 30, No. 2., pp. 213-229, DOI: https:// doi.org/10.1080/13537903.2015.1025542

Tuckman, B. W. (1974) An age-graded model for career development education. Journal of Vocational Behavior, Vol. 4, No. 2., pp. 193-212, DOI: https://doi. org/10.1016/0001-8791(74)90104-3

Van Tienen, M. - P. Scheepers - J. Reitsma - H. Schilderman (2011): The role of religiosity for formal and informal volunteering in the Netherlands. Voluntas, Vol. 22, No. 3., pp. 365-389, DOI: https://doi.org/10.1007/s11266-010-9160-6

Voicu, M. - B. Voicu (2003) Volunteering in Romania: A Rara Avis. In: Dekker, P. - L. Halman (eds.): The Values of Volunteering. Cross-Cultural Perspectives. New York, Boston, Dordrecht, London, Moscow, Kluver, Academic/Plenum Publishers. pp. 143-160, DOI: 10.1007/978-1-4615-0145-9

Wilson, J. (2000) Volunteering. Annual Review of Sociology, Vol. 26, No. 1., pp. 215-240, DOI: http://dx.doi.org/10.1146/annurev.soc.26.1.215

Wilson, J. - T. Janoski (1995) The contribution of religion to volunteer work. Sociology of Religion, Vol. 56, No. 2., pp. 137-152, DOI: https://doi. org $/ 10.2307 / 3711760$

Wilson, J. - M. Musick (1997) Who cares? Toward an integrated theory of volunteer work. American Sociological Review, Vol. 62, No. 3., pp. 694-713, DOI: https://doi.org/10.2307/2657355

Wirth, L. (1973) Az urbanizmus, mint életmód [Urbanism As a Lifestyle]. In: Szelényi, I. (ed.): Városszociológia [Urban Sociology]. Budapest, Közgazdasági és Jogi Könyvkiadó, pp. 41-64.

Wollebæk, D. - P. Selle (2003) Generations and Organizational Change. In: Dekker, P. - L. Halman (eds.): The Values of Volunteering. Cross-Cultural Perspectives. New York, Boston, Dordrecht, London, Moscow, Kluver Academic/Plenum Publishers, pp. 161-179, DOI: 10.1007/978-1-4615-0145-9 